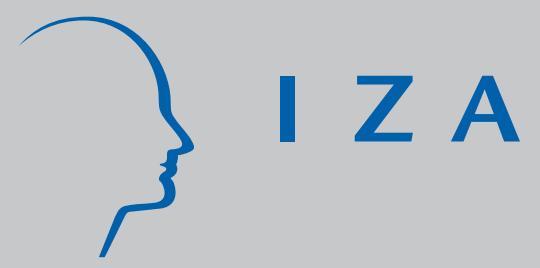

IZA DP No. 1197

Employee Training and Wage Compression in Britain

Filipe Almeida-Santos

Karen Mumford

J une 2004 


\title{
Employee Training and Wage Compression in Britain
}

\author{
Filipe Almeida-Santos \\ University of York \\ and Universidade Católica Portugesa \\ Karen Mumford \\ University of York and IZA Bonn
}

Discussion Paper No. 1197

June 2004

\author{
IZA \\ P.O. Box 7240 \\ 53072 Bonn \\ Germany \\ Phone: +49-228-3894-0 \\ Fax: +49-228-3894-180 \\ Email: iza@iza.org
}

Any opinions expressed here are those of the author(s) and not those of the institute. Research disseminated by IZA may include views on policy, but the institute itself takes no institutional policy positions.

The Institute for the Study of Labor (IZA) in Bonn is a local and virtual international research center and a place of communication between science, politics and business. IZA is an independent nonprofit company supported by Deutsche Post World Net. The center is associated with the University of Bonn and offers a stimulating research environment through its research networks, research support, and visitors and doctoral programs. IZA engages in (i) original and internationally competitive research in all fields of labor economics, (ii) development of policy concepts, and (iii) dissemination of research results and concepts to the interested public.

IZA Discussion Papers often represent preliminary work and are circulated to encourage discussion. Citation of such a paper should account for its provisional character. A revised version may be available on the IZA website (www.iza.org) or directly from the author. 
IZA Discussion Paper No. 1197

June 2004

\section{ABSTRACT}

\section{Employee Training and Wage Compression in Britain*}

We use linked data for 1,460 workplaces and 19,853 employees from the Workplace Employee Relations Survey 1998 to analyse the incidence and duration of employee training in Britain. We find training to be positively associated with having a recognised vocational qualification and current union membership. Whilst being non-white, shorter current job tenure, and part-time or fixed-term employment statuses are all associated with less training. Furthermore, in line with recent non-competitive training models, higher levels of wage compression (measured in absolute or relative terms) are positively related to training.

JEL Classification: J24, J31, J41

Keywords: training, wage compression, performance

Corresponding author:

Karen Mumford

Department of Economics and Related Studies

University of York

York Y010 5DD

United Kingdom

Email: kam9@york.ac.uk

\footnotetext{
* We thank the WERS98 sponsors - the Department of Trade and Industry, the Economic and Social Research Council, the Advisory, Conciliation and Arbitration Service and the Policy Studies Institute. They are not responsible for any of the findings or claims made in the paper. We also thank participants of various seminars, the ESAM 2003 meetings, and the anonymous referees for their helpful comments. Almeida-Santos is grateful for funding from the Fundacao para a Ciencia e Tecnologia - Ministerio da Ciencia e Tecnologia (Portugal) and Mumford is grateful for financial support from the Leverhulme Foundation.
} 


\section{Introduction}

Following Gary Becker's seminal contributions $(1962 ; 1964)$, training is usually categorised as either specific or general in nature. Employers may be prepared to offer general training to nonbonded employees if the wage rate is lowered to offset the training costs (as is often the case in apprenticeships). Otherwise, we would expect most employer provided training to be specific in nature increasing the productivity and the wage for the employee in their current workplace only.

Recent authors have extended Becker's work to consider training outcomes in a range of imperfectly competive enviroments finding that the theoretical distinction between general and specific training becomes obscured (Leuven, 2002; Polachek and Siebert, 1993; Stevens, 1994). For example, employers in the presence of asymmetric information may finance general training: the true level of training conferred may be unobservable to other firms (Chang and Wang, 1996; Katz and Ziderman, 1990) or training may allow the employer to obtain information regarding the quality of its workers in an independent manner (Acemoglu and Pischke, 1998, 1999a and 1999b). Imperfections in job search, the presence of efficiency wages, and labour-market institutions (such as union wage setting and minimum wages) may also compress the wage structure and motivate firms to invest in general training (Acemoglu and Pischke, 1998, 1999a, and 1999b). A dichotomy between general and specific training is also rarely observed empirically (Bishop, 1997).

Whilst the differences between general and specific training may be essentially notional, empirical investigation of the determinants of training (for both the firm and employee) and the potential returns from this training are still unresolved and are potentially very fruitful areas of research (Pischke, 2001:543; Leuven, 2002:34).

In this paper we use linked data from the British Workplace Employee Relations Survey 1998 (WERS98) to analyse the types of employees who engage in job related training, the characteristics of their workplaces, and a possible relationship between training and wage compression. 


\section{Data}

The data used in this study are drawn from the British Workplace Employee Relations Survey 1998 (WERS98), which was undertaken between October 1997 and June 1998. Interviews were conducted with a manager (with day-to-day responsibility for employee relations) and with a worker representative (if nominated) at 2,191 workplaces (all of which had more than 10 employees). Moreover, 25 employees from 1,880 of these workplaces were randomly selected (or all of the employees in workplaces with fewer than 26 employees) and asked to complete an employee questionnaire. The response rates were $80 \%$ for the face-toface workplace interviews and $64 \%$ for the employee questionnaire. All of these surveys are linkable.

There have been a limited number of studies using earlier versions of the WERS data sets (Millward et al., 2001). Collier et al., (2003) provide a study of training using WERS98 but they do not include evidence from the individual surveys in their analysis 2 . There has also been a range of studies of training in Britain typically using large cross sectional surveys or individual based cohort studies (surveys are provided in Shields, 1998; Blundell et al., 1996). We find that the linkable employee surveys in WERS98 add a major, and very valuable, component to these existing studies of training: providing for the possibility of separating out individual from workplace effects.

\section{Modelling training}

We adopt the Acemoglu and Pischke (AP) model as the basis for our empirical analysis of training. We present an abridged version of their model in this section, emphasising those features that will guide our variable choice in the empirical estimation presented in section 4 below.

Following along similar lines to Chang and Wang (1996) and Katz and Ziderman (1990), Acemoglu and Pischke (1998, 1999a and 1999b) construct a two-period model in which

\footnotetext{
${ }^{1}$ Department of Trade and Industry (1999). Workplace Employee Relations Survey: Cross-Section, 1998 (computer file). $4^{\text {th }}$ ed. Colchester: The Data Archive (distributor), 22 December 1999. SN: 3955.

${ }^{2}$ Since drafting this paper, we have become aware of a paper by Boheim and Booth (2003) that also uses WERS98 to explore training, however, they consider a more specific research interest to explore the link between trade union presence and training in the private sector. Nor do they consider wage compression. 
the worker is hired and receives training of $\tau$ in period 0 . Workers are assumed to have two different levels of ability $(\varphi)$ : low ability $\left(\varphi=\varphi_{1}\right)$ that occurs with a probability $p$ and high ability $\left(\varphi=\varphi_{\mathrm{h}}\right)$ that occurs with a probability $(1-p)$. The worker's marginal product, $y(\varphi, \tau)$, is a function of their ability $(\varphi)$ and skills acquired via training $(\tau)$ and is assumed to be increasing, differentiable and concave. The costs of training, $c(\tau)$, are assumed to be increasing, differentiable and convex.

Ability is assumed to be complementary with training, so that workers with high ability are more able to receive training, $\mathrm{y}(\tau, \varphi)=\tau \varphi$. The worker's actual ability will be known only at the end of period 0 , and the wage offered in the beginning of period 1 will be contingent to it: $w(\tau, \varphi)$.

The potential recruiting firm observes only the training level and offers in the beginning of the first period a wage contingent to it: $\mathrm{v}(\tau)$. The worker will quit if $w(\tau, \varphi)<\mathrm{v}(\tau)$ but due to exogenous reasons the worker may quit even when $v(\tau) \leq w(\tau, \varphi)$ with probability $\mu$, (where $0 \leq$ $\mu<1$ ). The authors also assume that with probability $q$ the firm will receive an adverse demand shock and the work relationship will come to an end.

The incumbent firm, in order to avoid the resignation of the worker, will offer in the beginning of the first period a wage equal to the one s/he would receive in the outside labour market: $\mathrm{w}(\varphi, \tau)=\mathrm{v}(\tau)$. The internal wage structure is therefore endogenous and set according to the outside wage offer (Acemoglu and Pischke, 1999a: 547). If the worker decides to quit after receiving the training, $\mathrm{s} / \mathrm{he}$ is assumed to face mobility or transactions costs (due, for example, to frictional costs related to job search imperfections) equal to $\Delta(\tau)$, with $\Delta^{\prime}(\tau)>0$.

For the firm, the resulting profit or surplus received will be equal to $\Delta(\tau)=y(\varphi, \tau)$ $\mathrm{w}(\varphi, \tau)$, which will be greater with higher levels of $\tau$. create a positive surplus to the training firm if the worker stays and, consequently, some incentive for the firm to invest in general training (Acemoglu and Pischke,1999b). The worker may, however, be able to extract some share, $Y$, of this surplus, where $0 \leq Y<1$.

\footnotetext{
${ }^{3}$ If the costs of moving between jobs $[\Delta=\mathrm{y}(\tau)-\mathrm{w}(\tau)]$ are independent of the level of training and $\mathrm{y}^{\prime}-\mathrm{w}^{\prime}=0$, the firm will not receive a benefit from providing training. 
To reiterate, the wage function is increasing in the level of training but at a lower rate than is productivity, $\mathrm{w}^{\prime}(\varphi, \tau)<\mathrm{y}^{\prime}(\varphi, \tau)$. The potential rents, $\Delta(\tau)$, obtained are higher at greater levels of $\tau$, leading to what the authors identify as a compressed wage structure. 'Wage compression arises naturally because the surplus brought to the employment relation is larger when the worker is more skilled, and the firm obtains a share of this larger pie' (Acemoglu and Pischke, 1999b: footnote 3).

The recruiting firm will expect a profit in the first period of:

$$
\pi=p\left[y\left(\tau, \varphi_{l}\right)-v(\tau)\right]+(1-p) \mu\left[y\left(\tau, \varphi_{h}\right)-v(\tau)\right]
$$

The training firm pays the cost of training for all workers in period 0 and obtains a profit of $\mathrm{y}\left(\tau, \varphi_{\mathrm{h}}\right)-\mathrm{v}(\tau)$ for each worker with high ability who decides to stay in period 1 . The fraction of high-ability workers continuing with the training firm is equal to $(1-p)(1-\mu)$ and expected profit is:

$$
\pi(\tau)=(1-p)(1-\mu)(1-\mathrm{Y})\left[y\left(\tau, \varphi_{h}\right)-v(\tau)\right]-c(\tau)
$$

The level of training will be chosen in order to guarantee the maximum profit ${ }^{4}$. The first order condition for training is:

$$
\pi^{\prime}(\tau)=(1-p)(1-\mu)(1-\mathrm{Y})\left[y^{\prime}\left(\tau, \varphi_{h}\right)-v^{\prime}(\tau)\right]-c^{\prime}(\tau)=0
$$

Indicating that the marginal return is equal to the marginal cost for a given level of training in equilibrium. The result that $\left[y^{\prime}\left(\tau, \varphi_{h}\right)-v^{\prime}(\tau)\right]$ is greater than 0 implies the presence of wage compression ${ }^{\mathrm{B}}$, since $v^{\prime}(\tau)=(1-p) \mu / p+(1-p) \mu<1$. Furthermore, as long as $\mathrm{Y}>0$ and $\mathrm{v}^{\prime}(\tau)>0$ or $\mu>0$, an increase in the turnover rate reduces general training investment and the equilibrium training level will be below the social optimum level.

\footnotetext{
${ }^{4}$ If the outside market is competitive, then the expected profit will be equal to zero, and the market wage is then given by: $v(\tau)=(1-p) \mu \tau /(p+(1-p) \mu)$.

5 "Intuitively, the presence of low-ability workers in the second-hand labor market implies that firms view workers in this market as lemons" (Acemoglu and Pischke, 1999b: 558). 
The firm has an incentive to invest in general training since there are complementarities between firm specific and general skills and because the bargaining share of the worker $(\mathrm{Y})$ and the marginal propensity to quit $(\mu)$ are both lower than one.

We adopt an essentially eclectic approach in the following econometric analysis, as is indicated by the range of empirical papers in the literature (Leuven, 2002), although we attempt to capture some of the major predictions of the Acemoglu and Pischke (AP) model. In particular, we seek variables reflecting employee's ability; the quit rate; adverse demand conditions; relative bargaining strength; the costs of training; the outside wage offer; and wage compression. Obviously, there are substantial overlaps across these categories and this needs to be taken into consideration in the following discussions.

\section{Variable definition and interpretation}

Summary statistics and variable definitions are provided in Table 1, with full sample means and standard deviations presented in columns one and two throughout the table, and means and standard deviations for the recently trained in columns 3 and 4 (more extensive variable definitions and descriptive statistics are available from the authors). Panel one of Table one presents summary statistics for employees' characteristics and panel two presents the summary statistics for workplaces. The data have been weighted to allow for stratification and clustering (Deaton, 1998) throughout the paper and, therefore, are representative of the sampling population.

\subsection{Training}

The WERS98 survey asked employees 'during the last twelve months, how much training have you had, either paid for or organized by your employer, away from the normal place of work, either on or off the premises?'. The respondent chose one of six bands, with the top band open-ended (more than 10 hours). The proportion of employees responding that they had received any employer provided training in Britain is substantial at $58 \%$ (column 1 , panel 1, of Table 1). Two different dependent variables will be used in our empirical analysis. The first dependent variable is binary; taking the value one if the worker received any training during the last year and zero otherwise (measuring the incidence of training). The second dependent variable is an underlying continuous variable (where we only observe 
an indicator for a particular range) and measures the number of days of training received during the last twelve months (reflecting the duration of training).

If we chose the midpoints for each of the first five of these bands and topcode the last band at 10 days, then on average, workers receive 2.46 days of this training a year, which is a relatively low value compared to other UK studies ${ }^{6}$ and may be prone to a range of measurements errors ${ }^{\mathrm{Q}}$.

\subsection{Ability}

To be able is not necessarily just to be clever. We select a range of variables typical of those generally associated with an individual's aptitude and opportunity (Leuven, 2002): potential work experience, highest earned education level, having a vocational qualification, current job tenure, being part-time or on a fixed term contract, gender, race, marital status, and being a parent.

Potential experience is computed as age minus years of schooling 8 minus 5 . Potential work experience is expected to be negatively related to training opportunities, ceteris paribus, reflecting a shorter time horizon for collecting returns from that training.

The expected relationship between education and training is positive if education and training are complementary and training increases ability (Bishop, 1997; page 75). The British workforce is not particularly well educated, indeed, $78 \%$ did not proceed with formal education beyond the end of secondary school ${ }^{2}$.

\footnotetext{
${ }^{6}$ Booth and Bryan (2002; table 2) using data from the British Household Panel Survey found the average duration of training to be 12.64 days in the late 1990s. Shields and Wheatley-Price (1999; table 3) using data from the Quarterly Labour Force Surveys found that just over half British training incidences lasted for more than a week in the mid 1990s (with a third lasting for more than a year).

${ }^{7}$ Measuring the duration of training accentuates possible errors due to recall bias, aggregation over potentially very heterogeneous training programmes, and timing ambiguities (Leuven, 2002; pages 27-29).

${ }^{8}$ We assume the following years of schooling for the different levels: Other Education Level, 5 years; CSE or equivalent, 10 years; O level or equivalent, 10 years; A level or equivalent, 12 years; Degree or equivalent, 15 years; Postgraduate degree or equivalent, 17 years.

${ }^{9}$ There are many 'others' most of who probably did not progress beyond primary education.
} 
Dummy variables are included in the regression analysis to allow for education: ' $\mathrm{O}$ level' set equal to one if the highest education level achieved is O-level, and 'above O-level' set equal to one if the highest education level achieved is above O-level, (the omitted category is leaving school before completing O-level). A binary variable is also included to indicate if the employee has a previous vocational qualification

On average, employees in Britain have current job tenure ${ }^{10}$ of 5.26 years (Mumford and Smith, 2004). The likelihood of training will decrease with the length of current job tenure (Bishop, 1997; Orrje, 2000) if hires that are more recent have greater need for job related training. We also included a binary variable to indicate new hires (set equal to one if current job tenure is less than one year).

We include measures of whether the employee is part-time (working less than 30 hours in a week) and/or employed on a temporary (fixed term) contract. In both cases, the firm has less potential time to reap the benefit from training and may be less prepared to pay the costs for it. The potential length of pay back period also declines with older workers (Becker, 1964). This age effect may be partially offset, however, as longer tenure reflects a quality match between firm and employee.

The demographic variables are self explanatory. We would expect from the literature on discrimination (Cain, 1986; Joshi and Paci, 1998) and segmented labour markets (Doeringer and Piore, 1971) that, if these demographic variables did have an impact on training, being female (especially with children), and non-white would be associated with less training.

Occupational choice is often treated in much the same way as educational outcome since they both reflect a range of variables, particularly individual ability and opportunity (Filer, 1986). WERS98 only covers those currently employed so these occupational choices may be also somewhat constrained (the 9 occupational groupings used in WERS are listed in

\footnotetext{
${ }^{10}$ Respondents were asked to choose a band ( 5 available bands) with a maximum value of 10 years or more, the latter band is coded at 10 years, and midpoint values set for the other bands.
} 
Table 1). Whilst less skilled occupations are associated with lower training levels and are expected to have lower levels of recent training, the occupational dummy variables are included primarily as control variables in the following regression analyses.

\subsection{Quit rate}

We proxy the AP quit rate with the percentage of the workplace workforce that has voluntarily resigned in the previous 12 months. The average value of this quit rate is $15 \%$ and is invariant to the presence of a formal workplace-training scheme.

\subsection{Bargaining strength}

We recognise that relative bargaining strength is a particularly complex measure (Mumford and Dowrick, 1994) and that variables impacting on this are very likely to also impact on other determinants of training (such as the quit rate and adverse demand conditions). With this in mind, we include measures of unionism (if the individual is a current union member, and if the workplace recognises union/s in the wage negotiation process) and if there is limited competition (five or fewer competitors) in the product market as indicators of relative bargaining strength.

\subsection{Adverse demand conditions}

At the time of being surveyed Britain had moved out of recession and was growing at $1 \%$ above its average rate for the period since 1980 . This growth is reflected in only $8 \%$ of the workplaces responding that the market for their main product or service was decreasing. this figure is slightly lower in the non-training workplaces at 7\%. The AP model predicts adverse demand conditions will be negatively related to training.

\subsection{Costs of training}

Measuring the costs of training is difficult especially given the heterogeneous nature of training (Leuven 2002; page 29). We have no explicit information on training costs. Nevertheless, we believe workplaces that are larger or older are more likely to have access to capital markets, and thereby be able to fund training programmes with greater ease. 
The organisation of the workforce may also impact on the ability of employees to cover for each other whilst in training and to share newly acquired skills. The proportion of the workforce in formally designated teams, the proportion of the non-managerial workforce in quality circles, multiple (within an enterprise) workplaces, and the presence of a human resource manager in the workplace are included in the analysis to reflect workplace organisation that is more conducive to training.

There may also be industry-based differences in the costs of training. For example, the costs of training in manufacturing may differ substantially from those in the service sectors. We do not have strong priors as to how these costs may be distributed and Table 1 reveals that there is very little industry-based difference across workplaces on average and those offering training. Industry dummy variables are therefore included as control variables in the following regression analysis.

\subsection{The outside wage}

We do not have a direct measure of the outside wage rate for employees, instead the local unemployment rate, a series of regional dummy variables (which will control for differences in regional wage rates) and a measure of the difficulty the workplace has in filling vacancies are incorporated in the analysis. We expect training to be positively related to the local unemployment rate and difficulty in filling vacancies. The regional dummy variables are included in the regressions as control variables.

We also include a range of variables that reflect the non-pecuniary nature of the job: if the workplace rewards seniority; if the workplace rewards ability; and an index of five family friendly work life balance measures ${ }^{11}$ (we believe that jobs with flexible working patterns would, ceteris paribus, be more attractive to employees (Budd and Mumford, 2004)).

\footnotetext{
${ }^{11}$ Flexible working hours, job sharing, parental leave, working at or from home in normal working hours, and workplace nursery or help with the cost of child care
} 


\subsection{Wage compression}

The AP model strictly requires an increase in absolute wage compression for firms to be willing to sponsor general training. Most tests of the model, however, consider a relative measure of wage compression (Acemoglu and Pischke, 1999b; Brunello 2001; Bassanini and Brunello, 2003). This relative measure is common in the labour economics literature and its familiarity (and the obvious interpretation and comparability of the ratio across markets) may explain its popularity. It is possible for absolute wage compression to rise without an increase in relative wage compression (Booth and Zoega, 2004, although, we expect this to be a relatively rare occurrence especially in recent history and when considering aggregate labour markets (Acemoglu, 2002). Nevertheless, in the empirical investigation below we will consider both absolute and relative measures of wage compression.

Following Acemoglu and Pischke (1999a), using the gross pay of full-time employees, we measure relative wage compression as the $\log$ of the ratio of the $90^{\text {th }}$ and the $10^{\text {th }}$ percentile levels of the wage distribution $\frac{12}{12}\left[\log \left(90^{\text {th }} / 10^{\text {th }}\right)\right]$. The absolute measure of wage compression is measured as the log of the difference between the $90^{\text {th }}$ and the $10^{\text {th }}$ percentile levels of the wage distribution for full time employees $\left[\log \left(90^{\text {th }}-10^{\text {th }}\right)\right]$.

As Brunello (2001) discusses, the average wage rate has little relevance for individual employees as an outside wage offer since earnings vary substantially by characteristics such as age, occupation, industrial sector and region. (Brunello's study uses data from the European Household Panel Survey and his measure of region is country based.) Using information on the gross wages of full-time employees, we similarly construct our wage compression measures with the highest attained level of education (6 bands), occupation (9 occupations), and industrial sector (12 industries). The education bands, occupations and industries used in the groupings are standard definitions (see Table 1 for definitions and summary statistics). This wage compression measure is then linked to individual employees

\footnotetext{
${ }^{12}$ The wage information provided in WERS is banded, we set each band value to its midpoint and top-coded at the starting value of the maximum category. A continuous, non-truncated wage measure would be preferable but is rarely available. We do not, however, believe this categorisation will seriously affect our wage compression measure. A related issue is discussed in Mumford and Smith (2004c) which explores the gender wage gap in Britain using WERS. They found no significant difference when using interval regression techniques.
} 
with the relevant (education, occupation and industry) characteristics to place them in that cell.

The higher the value of this measure the lower is wage compression, so we expect a negative relationship with our (either absolute or the relative) measure of wage compression and training according to the AP model.

\section{Econometric specification.}

\subsection{The incidence of training.}

The probability of the training $T$ of worker $i$ in workplace $k$ is given by:

$$
\begin{aligned}
& \operatorname{Pr}\left(T_{i k}=1\right)=\phi\left(\beta_{X_{i k}}\right), \\
& T_{i k}=1 \text { iff }{T_{i k}}^{*}>0, T_{i k}=0 \text { else, }
\end{aligned}
$$

where $X_{i k}$ is a vector of the explanatory variables thought to influence the decision to be train, and $\varnothing$ is the standard normal distribution function (Greene, 2001).

The presence of linked employee and employer workplace information also allows us to estimate models of training differentials across workplaces, conditional on the characteristics of individual workers. The model to be estimated is:

$$
\operatorname{Pr}\left(T_{i k}=1\right)=\phi\left(\beta_{X_{i}}+\alpha_{k}\right)
$$

where the probability of training worker $i$ in workplace $k\left(T_{i k}\right)$ is explained by a set of individual characteristics $\left(X_{i}\right)$ and a workplace specific effect $\left(\alpha_{k}\right)$. Workplace specific effects and individual characteristics are not assumed to be uncorrelated and we expect both types of effect to be important.

When evaluating the estimation results we compare estimates that omit the workplace specific effects (entitled probit in the tables) and those with them (entitled 
workplace effects). An issue that we can address by this comparison is that of segmentation. For example, among our demographic and occupational groupings we have groups who, in variety of different papers, have been identified as more likely to be in a different labour market segmented from the remainder (such as females and non-whites, see Doeringer and Piore, 1971; Joshi and Paci, 1998). A test of this idea can be carried out by comparison of the coefficients between the probit and the workplace specific effects results. For example, if a demographic identifier is significant in the probit estimates but not in the workplace specific effects estimates, then we can attribute the impact of membership of that demographic group to the workplace rather that to the worker's individual characteristic. This would be evidence suggesting segmentation.

\subsection{The duration of training.}

As discussed previously, the dependent variable measuring the duration of training is grouped into intervals and we only observe whether the duration of training falls into one of six different categories. Therefore, a variant of the ordered probit (an interval data regression model that allows for truncation beyond 10 days) will be used to analyse duration. Workplace specific effects will also be considered in a manner analogous to that described for the incidence of training.

\section{Results.}

Results for the probability of an employee training in the previous 12 months are presented in Table 2, and those for the duration of training are in Table 3. Columns 1 and 2 of each table provide results from estimation using only individual characteristics as explanatory variables; columns 3 and 4 reports results including workplace specific effects; and columns 5 and 6 present our preferred specification, which includes both individual and workplace characteristics in the estimation. 
We report marginal effects rather than raw coefficient estimates, except for binary variables where differential effects are reported ${ }^{163}$. The overall test of the explanatory power of the regressors is clearly significant for all the regressions and whilst the goodness of fit measures are not high, they are comparable with those found in other studies of training using cross-sectional data (see Leuven, 2002). Overall, the parameter estimates are generally well defined and have the expected sign.

We investigate the results in more detail by addressing the impact of the right hand side variables in turn. Beginning with the demographic measures, we find no consistent significant differences in the probability of training for those living with a spouse or partner. We find females are not significantly more or less likely to receive training than males, but that the duration of training spells for females is significantly shorter than for males. Moving from column 1 to 3 in Table 3, we can see that the extent of this difference decreases indicating that females are more likely to work in workplaces that offer shorter training periods training than do males. Once we allow fully for this workplace specific effect, we no longer find a significant difference between men and women in the duration of their training spells.

Non-whites are consistently found to have less training (both incidence and duration) in the previous 12 months in our results. A similar result has been found for Britain by Shields and Wheatley-Price (1999) using the Quarterly Labour Force Survey (see also Lynch, 1992; Veum, 1993). Moving from column 1 to 3 in Tables 2 and 3, we can see that the extent of this difference decreases indicating that non-whites are less likely to work in workplaces that offer training than do whites. After fully allowing for the workplace specific effect, however, we still find that non-whites are still less likely to train than are whites. The empirical findings on the impacts of race and gender on training are not clear in the literature (Frazis et al., 1998) and may differ according to the type of training being offered (Leuven, 2002). Our results suggest that there may be some segmentation occurring in the British labour market resulting in females and non-whites being concentrating in low training workplaces.

\footnotetext{
${ }^{13}$ We also include multiplicative education and tenure, and multiplicative education and potential experience, terms to capture possible interactions with education in the regressions. 
We find mixed results for the impact of ability on training. Workers with low education levels are not found to be significantly less likely to be recently trained, as predicted. Nor are those with high education levels consistently found to have more access to training. Training is, however, found to be strongly and positively related to previous vocational qualification as predicted. Perhaps indicating that these qualifications signal that the employee has previously been successful in work related training and/or that these employees may have a taste for training. Potential work experience is found to be significantly related to training only through the quadratic term, overall there is a very small and insignificant negative effect (at the mean) from potential work experience on the duration of training but no significant impact on the incidence of training. The theoretically predicted declining relationship between age and training may not be strong in Britain (Shields, 1998: page 191). This finding is not, however, common in the literature for other countries (Leuven, 2002).

The level of current job tenure is found to be negatively and significantly associated with training as predicted, the quadratic is positive. At the mean, the negative effect dominates for both duration and incidence of training. Similar results are found in Orrje (2000) and Bishop (1997). We found inconsistent results for the likelihood of new hires to be trained. It may be that the shorter time period these employees have had to be offered training is confounding our results. We found the quit rate to be significantly and negatively related to the incidence of training, as predicted. Similarly, we find that temporary employees (those on a fixed-term contract) are less likely to be trained, as predicted by the AP model.

Considering bargaining strength, we found current union membership to be consistently, positively and significantly associated with training. The size of this effect is diminished as we incorporate workplace characteristics including union recognition (moving from column 1 to 5), then rises substantially when the full set of workplace specific effects are included (column 3). Unionism is clearly associated with more training (both incidence and duration), however, the relationship is apparently more complex than the simple measures of union density and recognition that we include in our analysis. The impact of unionism on training is far from uniform in the literature (Frazis et al., 1998; Shields, 1998) and there is obviously much more that can be done in this area in future work (Boheim and Booth, 2003). 
We do not find a significant relationship between the workplace having limited competition in the product market and employee training. This may be due to potential ambiguities in this variable. For example, whilst firms with limited competition may have greater surplus to spend on training it may also be that firms operating in competitive product markets may be under more pressure to introduce new technology via training (Caballero and Hammour, 1994). We also do not find a significant relationship between adverse demand conditions and training; however, as we only have cross sectional data and this was a year of strong growth, we may not have information on enough workplaces to measure this effect accurately.

Organisational structures which may lower the costs of training are found to have a substantial relationship with the probability of recent training: the proportions of the workforce in quality circles and in designated teams are both positively associated with recent training. Similarly, workplaces that are part of a multiple enterprise structure and/or have a human resource manager provide more training. We do not find strong relationships between the workplace age, workplace size or being in the public sector and training. These results suggest that it is explicit organisational structures implemented by management, rather than the simple physical attributes of the workplace, that are important predictors for training.

Our measures of the outside wage are not consistently related to training: the impact of the local unemployment rate is insignificant as is the difficulty the firm has in filling vacancies. The regional dummy variables are found to be significant, however, and may be capturing this relationship.

Finally, in line with recent non-competitive training models, higher levels of relative wage compression are associated with a greater incidence and duration of training (which is revealed by consistent negative and significant findings for our relative wage compression 14 measure in Tables 2 and 3).

\footnotetext{
${ }^{14}$ It may be argued that the wage compression measure is endogenous. As a guide to the extent of this problem for our empirical estimations, we carried out a Hausman test for endogeniety on our relative wage compression measure in our preferred model for the incidence of training and found the coefficient on the obtained residuals to be significantly different from zero (at a probability level of 0.006 ).
} 
As discussed above, the AP model strictly refers to a relationship between absolute wage compression and training, although it has commonly been tested with a relative measure. We address this issue by using the absolute wage compression measure in place of the relative measure in our preferred model for both incidence and duration (the full regressions reported in columns 5 and 6 of tables 2 and 3); the regressions remained the same in all other regards. The results for alternative wage compression measures are presented in Table 4. The results for the relative and absolute wage compression measures are very similar $\frac{15}{15}$. higher wage compression is associated with a greater probability of training; and, less significantly, to longer training periods.

Furthermore, we considered dividing the wage compression measure so as to explore the upper and lower halves of the distribution separately (for both the absolute and relative measures). Whilst all forms of wage compression may generate increased training in the AP model, we would expect this relationship to be stronger in the upper end of the distribution as more skills lead to larger surpluses to be shared between the firm and employee (Acemoglu and Pischke, 1999b: footnote 3). Indeed, we find that it is wage compression in the upper end of the distribution (between the $90^{\text {th }}$ and the $50^{\text {th }}$ percentiles) that is associated with more training (see Table 4).

\section{Conclusions}

We use linked data for 1,460 workplaces and 19,853 employees from the Workplace Employee Relations Survey 1998 to analyse the incidence and duration of employee training. We find training to be positively associated with having a recognised vocational qualification and current union membership. Whilst being non-white, shorter current job tenure, and being on a fixed-term contract are all associated with less training. Our results also suggest that there may be some segmentation occurring in the British labour market resulting in females and non-whites being concentrating in low training workplaces.

\footnotetext{
${ }^{15}$ The relative wage compression measure tends to have a more significant relationship with training than does the absolute measure. This is particularly apparent when considering absolute wage compression and the duration
} 
In line with recent non-competitive training models, higher levels of wage compression are positively related to training (both incidence and duration). This result is consistent when using either an absolute or relative measure of wage compression: supporting the interchangeable use of these measures of wage compression in the literature (Acemoglu and Pischke, 1999a: 542). Furthermore, we find that it is wage compression in the upper half of the distribution (between the $90^{\text {th }}$ and the $50^{\text {th }}$ percentiles) that is significantly associated with more training.

Our results may be seen as a further empirical investigation of the determinants of training (for both the firm and employee) and the potential returns from this training which helps to fill the gap in a still unresolved area of research (Pischke, 2001: 543, Leuven, 2002: 34). Our results are also generally supportive of the new non-competitive training models and, in particular, the behavioural axioms presented by Acemoglu and Pischke (1998, 1999a, and 1999b).

of training where the relationship is not significant at standard confidence levels (the confidence levels for the $\mathrm{z}$ values of -1.36 and -1.60 are $83.6 \%$ and $89 \%$ respectively). 


\section{References}

Abowd, J.M. Kramarz, F. and D.N. Margolis, 1999, High Wage Workers and High Wage Firms, Econometrica 67(2), 251-334.

Acemoglu, D., 2002, Technical Change, Inequality and the Labour Market, Journal of Economic Literature 40: 7-72.

Acemoglu, D. and J.S. Pischke, 1998, Why do Firms Train? Theory and Evidence, Quarterly Journal of Economics 113(1): 79-119.

-----, 1999a, The Structure of Wages and Investment in General Training, Journal of Political Economy 107(3): 539-572.

-----, 1999b, Beyond Becker: Training in Imperfect Labor Markets, Economic Journal 109: F112F142.

Ariga, K. and G. Brunello, 2002, Are the More Educated Receiving More Training? Evidence from Thailand. IZA DP 577.

Bassanini, A., and G. Brunello, 2003, Is Training More Frequent when Wage Compression is Higher? Evidence from the European Community Household Panel, IZA DP 839.

Becker, G.S., 1962, Investment in Human Capital: A Theoretical Analysis, Journal of Political Economy 70: 9-49.

Becker, G.S., 1964, Human Capital: A Theoretical and Empirical Analysis, with Special Reference to Education (The University of Chicago Press, $3^{\text {rd }}$ Edition, Chicago).

Bishop, J.H., 1997, What We Know about Employer-Provided Training? A Review of the Literature, Research in Labor Economics 16: 19-87.

Blundell, R., Dearden, L. and C. Meghir, 1996, The Determinants and Effects of Work-Related Training in Britain, Mimeo, Institute for Fiscal Studies.

Boheim, R. and A.L.Booth, 2003, Trade Union Presence and Employer-Provided Training in Britain, forthcoming in Industrial Relations.

Booth, A.L. and M. L. Bryan, 2002, Who Pays for General Training? Mimeo ISER, University of Essex.

Booth, A.L. and G. Zoega, 2004, Is Wage Compression a Necessary Condition for Firm-Financed General Training? forthcoming in Oxford Economic Papers.

Brunello, G., 2001, Is Training More Frequent when Wage Compression is Higher? Evidence from 11 European countries, PuRE publications, The Research Institute of the Finnish Economy.

Budd, J.W. and K.A. Mumford, 2004, Trade Unions and Family Friendly Work Policies in Britain, Industrial and Labor Relations Review: 57(2): 204-222. 
Caballero, R.J. and M.L. Hammour, 1994, The Cleansing Effect of Recessions, American Economic Review 84(5); 1075-1084.

Cain, G.C., 1986, The Economic Analysis of Labor Market Discrimination: A Survey. in O. Ashenfelter, and R. Layard, eds., Handbook of Labor Economics. Vol. 1 (North Holland, Amsterdam): 693-785.

Chang, C. and Y. Wang, 1996, Human Capital Investment under Asymmetric Information: The Pigovian Conjecture Revisited, Journal of Labor Economics 14(3): 505-519.

Collier, W., Green, F., Peirson, J. and D. Wilkinson, 2003, Training and Establishment Survival, Mimeo, University of Kent.

Deaton, A., 1998, The Analysis of Household Surveys. A Microeconometric Approach to Development Policy, World Bank (Baltimore: John Hopkins University Press).

Doeringer, P. B. and M.J. Piore, 1971, Internal Labor Markets and Manpower Analysis. (Massachusetts: D.C.Heath).

Filer, R., 1986, The Role of Personality andTtastes in Determining Occupational Structure, Industrial and Labor Relations Review 39: 412-424.

Frazis, H., M., Gittleman, and W. Joyce, 1998, Determinants of Training: An Analysis using Both Employer and Employee Characteristics, Mimeo, Bureau of Labor Statistics, Washington.

Greene, W.H. (2001), Econometric Analysis, $4^{\text {th }}$ Edition. New Jersey: Prentice Hall International.

Joshi, H. and P. Paci, 1998, Unequal Pay for Men and Women. (Cambridge Massachusetts: MIT Press).

Katz, E. and A. Ziderman, 1990, Investment in General Training: The Role of Information and Labour Mobility, Economic Journal 100(403): 1 147-1 158.

Leuven, E., 2002, The Economics of Training: A Durvey of the Literature, Mimeo, retrieved on http://www.fee.uva.nl/scholar/mdw/leuven/reviewart.pdf

Lynch, L. M. 1992, Differential Effects of Post-School Training on Early Career Mobility, Working Paper NBER 4034;

Loewenstein, M.A. and J.R. Spletzer, 1998, Dividing the Costs and Returns to General Training, Journal of Labor Economics 16 (1): 142-171.

McIntosh, S., 1999, A Cross Country Comparison of the Determinants of Vocational Training. CEP DP 432.

Millward, N., Woodland, S., Bryson, A., Forth, J., and Simon Kirby. 2001. A Bibliography of Research Based on the British WIRS Series. Mimeo NIESR, London.

Mumford, K. and S. Dowrick, 1994, Wage Bargaining with Endogenous Profits, Overtime Working and Heterogenous Labor, Review of Economics and Statistics 76(2); 329-336. 
Mumford, K. and P.N. Smith, 2004, Job Tenure in Britain: Employee Characteristics versus Workplace Effects, Economica 71: 275-298.

Orrje, H., 2000, The Incidence of On-the-Job Training. An Empirical Analysis using Swedish Data, Working Paper 6/2000, Swedish Institute for Social Research.

Pischke, J.S., 2001, Continuous Training in Germany, Journal of Population Economics 14, 523548.

Polachek, S. and S. Siebert, 1993, The Economics of Earnings (Cambridge: Cambridge University Press).

Shields, M., 1998, Changes in the Determinants of Employer-Funded Training for Full-Time Employees in Britain, 1984-1994, Oxford Bulletin of Economics and Statistics 60(2), 189214.

Shields, M., and S. Wheatley-Price, 1999, Ethnic Differences in the Incidence and Determinants of Employer-Funded Training in Britain, Scottish Journal of Political Economy 46(5), 523551.

Stevens, M., 1994, A Theoretical Model of On-the-Job-Training with Imperfect Competition, Oxford Economic Papers 46, 537-563.

Veum, J. R. 1993, Training Among Young Adults: Who, What Kind and for How Long? Monthly Labor Review, 27-32. 
Table 1. Variable definitions and means

\begin{tabular}{|c|c|c|c|c|}
\hline & \multicolumn{2}{|c|}{ All } & \multicolumn{2}{|c|}{ With Training } \\
\hline & $\begin{array}{l}\text { Mean } \\
\text { (1) }\end{array}$ & $\begin{array}{c}\text { Std Dev } \\
\text { (2) }\end{array}$ & $\begin{array}{c}\text { Mean } \\
\text { (3) }\end{array}$ & $\begin{array}{c}\text { Std Dev } \\
\text { (4) }\end{array}$ \\
\hline \multicolumn{5}{|l|}{ (1) Individual employee characteristics } \\
\hline Trained in previous 12 months & 0.58 & 0.49 & 1.00 & 0.00 \\
\hline Length of training in previous 12 months & 2.43 & 3.22 & 4.15 & 3.26 \\
\hline Potential experience & 23.96 & 13.24 & 22.20 & 12.53 \\
\hline Female & 0.47 & 0.50 & 0.48 & 0.50 \\
\hline Living with spouse or partner & 0.69 & 0.46 & 0.68 & 0.46 \\
\hline Not-white & 0.04 & 0.18 & 0.03 & 0.18 \\
\hline Any dependent children aged 0-18 & 0.41 & 0.49 & 0.43 & 0.49 \\
\hline O ther education level & 0.24 & 0.43 & 0.17 & 0.38 \\
\hline CSE or equivalent & 0.13 & 0.34 & 0.11 & 0.31 \\
\hline O level or equivalent & 0.27 & 0.45 & 0.29 & 0.45 \\
\hline A level or equivalent & 0.15 & 0.36 & 0.18 & 0.38 \\
\hline Degree or equivalent & 0.15 & 0.36 & 0.19 & 0.40 \\
\hline Postgraduate degree or equivalent & 0.05 & 0.21 & 0.06 & 0.24 \\
\hline Education below O-level & 0.37 & 0.48 & 0.28 & 0.45 \\
\hline Education above 0 -level & 0.35 & 0.48 & 0.43 & 0.49 \\
\hline Recognised vocational qualification & 0.38 & 0.49 & 0.41 & 0.49 \\
\hline Current job tenure & 5.26 & 3.63 & 5.03 & 3.64 \\
\hline Current job tenure less than 1 year (new hires) & 0.17 & 0.38 & 0.18 & 0.39 \\
\hline Log Hours & 3.48 & 0.56 & 3.52 & 0.52 \\
\hline Part-time & 0.25 & 0.43 & 0.23 & 0.42 \\
\hline Temporary & 0.04 & 0.20 & 0.03 & 0.18 \\
\hline Current union member & 0.37 & 0.48 & 0.40 & 0.49 \\
\hline Wage compression (90 to 10 percentile) relative & 0.87 & 0.28 & 0.86 & 0.28 \\
\hline Wage compression (90 to 10 percentile) absolute & & & & \\
\hline \multicolumn{5}{|l|}{0 ccupations } \\
\hline Managers and senior administrators & 0.09 & 0.29 & 0.11 & 0.31 \\
\hline Professionals & 0.13 & 0.34 & 0.17 & 0.37 \\
\hline Associate Professional and technical & 0.08 & 0.27 & 0.10 & 0.29 \\
\hline Clerical and secretarial & 0.16 & 0.37 & 0.17 & 0.37 \\
\hline Craft and skilled service & 0.11 & 0.32 & 0.08 & 0.28 \\
\hline Personal and protective services & 0.09 & 0.28 & 0.11 & 0.31 \\
\hline Sales operator, sales assistant & 0.11 & 0.31 & 0.12 & 0.33 \\
\hline O perative and assembly & 0.14 & 0.34 & 0.09 & 0.28 \\
\hline O ther occupational group & 0.10 & 0.30 & 0.06 & 0.25 \\
\hline \multicolumn{5}{|l|}{ (2) W orkplace characteristics } \\
\hline Formal training scheme operates from the workplace & 0.87 & 0.34 & 0.92 & 12.10 \\
\hline Proportion of workforce trained in previous 12 months & 0.60 & 0.24 & 0.70 & 12.79 \\
\hline Proportion of workforce resigned in the last 12 months & 0.15 & 0.20 & 0.14 & 14.14 \\
\hline Decreasing market for product or service & 0.08 & 0.28 & 0.07 & 22.12 \\
\hline Workplace operates in the public sector & 0.26 & 0.44 & 0.31 & 8.85 \\
\hline Workplace faces limited competition in the product market & 0.35 & 0.48 & 0.34 & 17.22 \\
\hline Number of employees in workplace & 498.56 & 1618.19 & 492.63 & 95.09 \\
\hline Age of the current workplace & 38.02 & 45.17 & 37.72 & 16.07 \\
\hline Workplace is one of multiple workplaces in enterprise & 0.74 & 0.44 & 0.80 & 14.78 \\
\hline Recognised union(s) in workplace & 0.58 & 0.49 & 0.60 & 13.96 \\
\hline Workplace has a human resources employee & 0.43 & 0.49 & 0.46 & 13.47 \\
\hline
\end{tabular}




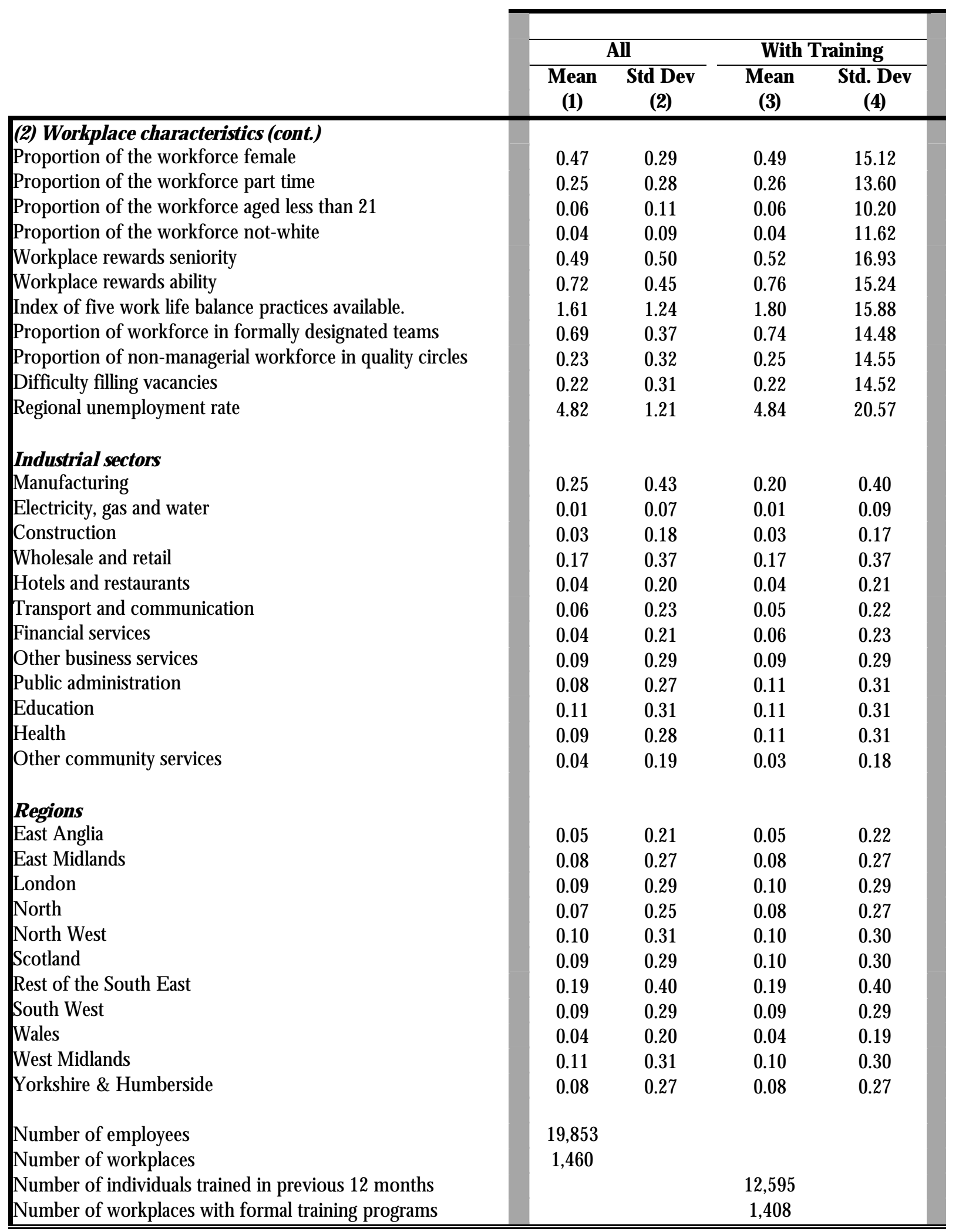

Source: Workplace Employee Relations Survey, 1998. The sample means and standard errors are fully weighted to account for stratification and clustering in the sampling procedure. 
Table 2. Probability that the employee has recently trained.

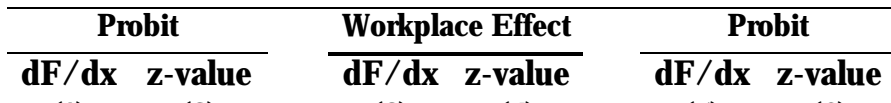

Individual measures
(1)
(2)
(3)
(4)
(5)
(6)

\begin{tabular}{|c|c|c|c|c|c|c|}
\hline Potential experience & 0.002 & 0.69 & -0.001 & -0.37 & -0.000 & -0.08 \\
\hline Potential experience squared (x1000) & -0.000 & $-2.03^{* *}$ & -0.000 & -1.25 & -0.000 & -1.07 \\
\hline Female & -0.008 & -0.68 & -0.008 & -0.47 & -0.025 & $-1.86^{*}$ \\
\hline Living with spouse or partner & 0.005 & 0.41 & -0.001 & -0.04 & 0.002 & 0.14 \\
\hline Not-white & -0.090 & $-3.48^{* * *}$ & -0.080 & $-2.53^{* *}$ & -0.079 & $-2.82^{* * *}$ \\
\hline Any dependent children aged 0-18 & 0.009 & 0.73 & -0.003 & -0.20 & 0.011 & 0.86 \\
\hline Education O-level & 0.042 & 1.20 & -0.002 & -0.04 & 0.020 & 0.57 \\
\hline Education above 0-level & 0.069 & $2.00^{\star *}$ & 0.045 & 0.97 & 0.033 & 0.93 \\
\hline Current job tenure & -0.054 & $-5.26^{\star * *}$ & -0.031 & $-2.05^{\star *}$ & -0.055 & $-5.46^{\star \star \star}$ \\
\hline Current job tenure squared & 0.004 & $4.39^{\star \star \star}$ & 0.002 & 1.59 & 0.004 & $4.45^{\star \star \star}$ \\
\hline Current Job tenure lower than 1 & -0.043 & $-1.88^{*}$ & -0.046 & -1.45 & -0.045 & $-1.96^{\star *}$ \\
\hline Recognised vocational qualification & 0.051 & $4.77^{* \star *}$ & 0.021 & 1.44 & 0.045 & $4.18^{\star * *}$ \\
\hline Log Hours & -0.068 & $-2.24^{* *}$ & 0.041 & 0.83 & 0.002 & 0.07 \\
\hline Part-time & -0.542 & $-4.57^{\star * *}$ & -0.134 & -0.64 & -0.318 & $-2.49^{* *}$ \\
\hline Log Hours * Part-time & 0.156 & $4.22^{\star \star *}$ & 0.031 & 0.52 & 0.074 & $2.01^{\star *}$ \\
\hline Temporary & -0.116 & $-4.26^{* * *}$ & -0.122 & $-3.11^{* * *}$ & -0.123 & $-4.53^{\star * *}$ \\
\hline Current union member & 0.110 & $9.81^{* * *}$ & 0.128 & $7.11^{* * *}$ & 0.052 & $4.07^{* * *}$ \\
\hline Wage compression (90-10 percentile) & -0.078 & $-3.58^{* * *}$ & -0.073 & $-2.50^{* *}$ & -0.066 & $-2.87^{* * *}$ \\
\hline O ccupation dummies & & Yes $* * *$ & & Yes. ${ }^{* * *}$ & & Yes ${ }^{* * *}$ \\
\hline Industry dummies & & & & & & $\mathrm{Yes}^{\star * *}$ \\
\hline Regional dummies & & & & & & $\mathrm{Yes}^{\star * *}$ \\
\hline \multicolumn{7}{|c|}{ W orkplace measures } \\
\hline \multicolumn{5}{|c|}{ Proportion of the workforce resigned in the last 12 months } & -0.087 & $-3.07^{\star \star \star}$ \\
\hline \multicolumn{5}{|c|}{ D ecreasing market for product or service } & -0.029 & -1.59 \\
\hline \multicolumn{5}{|c|}{ Workplace operates in the public sector } & -0.001 & -0.03 \\
\hline \multicolumn{5}{|c|}{ Workplace faces limited competition in the product market } & 0.011 & 1.00 \\
\hline \multicolumn{5}{|c|}{ Number of employees in workplace (/ 1000) } & -0.006 & -0.72 \\
\hline \multicolumn{5}{|l|}{ Age of the current workplace (/ 1000) } & -0.033 & -0.28 \\
\hline \multicolumn{5}{|c|}{ Workplace is one of multiple workplaces in enterprise } & 0.094 & $7.46^{\star * \star}$ \\
\hline \multicolumn{5}{|c|}{ Recognised union(s) in workplace } & -0.025 & $-1.84^{*}$ \\
\hline \multicolumn{5}{|c|}{ Workplace has a human resources employee } & 0.056 & $5.07^{\star \star *}$ \\
\hline \multicolumn{5}{|l|}{ Proportion of the workforce female } & -0.010 & -0.32 \\
\hline \multicolumn{5}{|c|}{ Proportion of the workforce part time } & 0.132 & $4.00^{* * *}$ \\
\hline \multicolumn{5}{|c|}{ Proportion of the workforce aged less than 21} & -0.090 & -1.46 \\
\hline \multicolumn{5}{|c|}{ Proportion of the workforce not-white } & 0.093 & 1.50 \\
\hline \multicolumn{5}{|l|}{ Workplace rewards seniority } & 0.004 & 0.37 \\
\hline \multicolumn{5}{|c|}{ Workplace rewards ability } & 0.039 & $3.30^{* \star *}$ \\
\hline \multicolumn{5}{|c|}{ Index of 5 work life balance practices available in } & & \\
\hline \multirow{2}{*}{\multicolumn{5}{|c|}{$\begin{array}{l}\text { workplace } \\
\text { Proportion of workforce in formally designated teams }\end{array}$}} & 0.025 & 5.25 \\
\hline & & & & & 0.084 & $5.90^{\star \star *}$ \\
\hline \multicolumn{5}{|c|}{ Proportion of non-managerial workforce in quality circles } & 0.063 & $4.06^{\star \star \star}$ \\
\hline \multicolumn{5}{|c|}{ Difficulty filling vacancies } & 0.017 & 1.06 \\
\hline \multicolumn{3}{|l|}{ Regional unemployment rate } & & & -0.000 & -0.03 \\
\hline Number of observations & \multicolumn{2}{|l|}{19,853} & 19.853 & & 19,853 & \\
\hline F test & $31.76^{* * *}($ & ,1361) & & & $20.97(6$ & ,1322) \\
\hline Pseudo R squared & 0.1056 & & & & 0.1353 & \\
\hline Predicted mean of the dependent & 0.59 & & 0.59 & & 0.60 & \\
\hline Wald chi2 & $1489 * * *$ & (30) & $531 * * *$ & (69) & $1992.95 * \star$ & \\
\hline
\end{tabular}


Source: Workplace Employee Relations Survey, 1998. All regressions are fully weighted to allow for stratification and clustering in the sampling procedure: 70 strata, 1445 PSUs. *Statistically significant at $90 \%$, $* *$ at $95 \%$, and at $* * * 99 \%$. 
Table 3. The duration of training

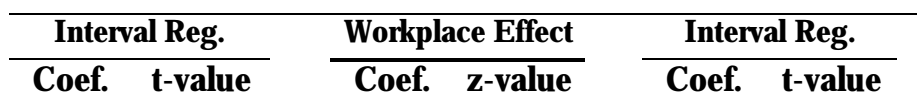

Individual measures

Potential experience

Potential experience squared (x1000)

Female

Living with spouse or partner

Not-white

Any dependent children aged 0-18

Education O-level

Education above O-level

Current job tenure

Current job tenure squared

Current Job tenure lower than 1

Recognised vocational qualification

Log Hours

Part-time

Log Hours * Part-time

Temporary

Current union member

Wage compression (90-10 percentile)

Occupation dummies

Industry dummies
(2)

0.014

$-0.001$

$-0.156$

0.034

$-0.423$

$-0.038$

0.191

0.248

$-0.286$

0.019

$-0.167$

0.371

$-0.174$

$-2.817$

0.728

$-0.676$

0.625

$-0.422$

(3)

(4)

(5)

(6)

\begin{tabular}{|c|c|c|c|c|}
\hline 0.96 & -0.010 & -1.19 & 0.008 & 0.48 \\
\hline$-2.74^{* * *}$ & 0.000 & $-1.73^{*}$ & -0.001 & $-2.30^{* *}$ \\
\hline$-2.03^{* *}$ & -0.064 & -1.57 & -0.274 & $-3.01^{* * *}$ \\
\hline 0.52 & -0.003 & -0.09 & 0.030 & 0.31 \\
\hline$-3.02^{* * *}$ & -0.307 & $-3.40^{* * \star}$ & -0.397 & $-1.95^{*}$ \\
\hline-0.54 & -0.006 & -0.14 & -0.054 & -0.58 \\
\hline 1.07 & -0.014 & -0.12 & -0.012 & -0.05 \\
\hline 1.21 & -0.030 & -0.25 & -0.043 & -0.16 \\
\hline$-4.88^{* * *}$ & -0.250 & $-7.43^{* * *}$ & -0.196 & $-2.40^{\star *}$ \\
\hline $3.89^{* * *}$ & 0.015 & $5.65^{\star * \star}$ & 0.012 & $1.86^{*}$ \\
\hline-1.55 & -0.201 & $-2.68^{* * *}$ & -0.235 & -1.53 \\
\hline $6.16^{* * *}$ & 0.218 & $6.23^{* * \star}$ & 0.319 & $3.81^{* * *}$ \\
\hline-0.83 & 0.016 & 0.15 & 0.270 & 1.05 \\
\hline$-2.98^{* * *}$ & -2.605 & $-5.72^{* * *}$ & -0.776 & -0.69 \\
\hline $2.63^{* * *}$ & 0.688 & $5.16^{\star * \star}$ & 0.143 & 0.43 \\
\hline$-4.17^{* \star *}$ & -0.506 & $-5.34^{* * \star}$ & -0.723 & $-3.15^{\star * *}$ \\
\hline $8.04^{* * *}$ & 0.400 & $9.36^{\star * \star}$ & 0.411 & $3.95^{\star * \star}$ \\
\hline$-2.95^{\star * \star}$ & -0.149 & $-1.94^{*}$ & -0.343 & $-1.98^{\star *}$ \\
\hline Yes ${ }^{\star * *}$ & & Yes. ${ }^{* \star \star}$ & & $\begin{array}{l}\text { Yes } S^{\star \star \star} \\
\text { Yes }\end{array}$ \\
\hline
\end{tabular}

\section{W orkplace measures}

Decreasing market for product or service

$-0.314 \quad-1.38$

Workplace operates in the public sector

Workplace faces limited competition in the product market

Number of employees in workplace (/ 1000)

Age of the current workplace (/ 1000)

Workplace is one of multiple workplaces in enterprise

Recognised union(s) in workplace

Workplace has a human resources employee

Proportion of the workforce female

Proportion of the workforce part time

Proportion of the workforce aged less than 21

Proportion of the workforce not-white

Workplace rewards seniority

Index of 5 work life balance practices available in

workplace

Proportion of workforce in formally designated teams

Proportion of non-managerial workforce in quality circles

D ifficulty filling vacancies

19.853

Number of observations

$34,17 * * *(30,1361)$

19.853

$0.064 \quad 0.34$

$0.035 \quad 0.28$

$0.142 \quad 1.18$

$-0.292 \quad-0.12$

$0.5653 .65^{\text {***}}$

$0.036 \quad 0.26$

$0.209 \quad 1.52$

$\begin{array}{ll}-0.340 & -0.82\end{array}$

$0.740 \quad 1.86$ *

$-0.448 \quad-0.70$

$\begin{array}{ll}-0.113 & -0.14\end{array}$

$-0.134 \quad-1.09$

$0.119 \quad 2.24$

$0.253 \quad 1.73^{*}$

$0.3702 .33^{* *}$

$0.057 \quad 0.30$

$\mathrm{F}$ test

Wald Chi2

2292

(30).

Source: Workplace Employee Relations Survey, 1998. All regressions are fully weighted to allow for stratification and clustering in the sampling procedure: 70 strata, 1445 PSUs. *Statistically significant at $90 \%$, $* *$ at $95 \%$, and at $* * * 99 \%$. 
Table 4. Altemative measures of wage compression.

\begin{tabular}{|c|c|c|c|c|c|}
\hline \multirow[b]{3}{*}{$\begin{array}{l}\text { Relative wage } \\
\text { compression }\end{array}$} & \multicolumn{2}{|c|}{ Incidence } & & \multicolumn{2}{|c|}{ Duration } \\
\hline & $\begin{array}{l}\mathrm{dF} / \mathrm{dx} \\
\text { (1) }\end{array}$ & $\begin{array}{l}\text { t-value } \\
\text { (2) }\end{array}$ & & $\begin{array}{l}\mathrm{dF} / \mathrm{dx} \text {. } \\
\text { (3) }\end{array}$ & $\begin{array}{c}\text { t-value } \\
\text { (4) }\end{array}$ \\
\hline & & & & & \\
\hline $\log \left(90^{\text {th }} / 10^{\text {th }}\right.$ percentile $)$ & -0.066 & $-2.87 * * *$ & : & -0.343 & $-1.98 * *$ \\
\hline $\log \left(90^{\text {th }} / 50^{\text {th }}\right.$ percentile $)$ & -0.123 & $-3.27 * * *$ & : & -0.674 & $-2.52 * * *$ \\
\hline $\log \left(50^{\text {th }} / 10^{\text {th }}\right.$ percentile $)$ & -0.027 & -0.87 & & -0.096 & -0.41 \\
\hline \multicolumn{6}{|l|}{$\begin{array}{c}\text { Absolute wage } \\
\text { compression }\end{array}$} \\
\hline $\log \left(90^{\text {th }}-10^{\text {th }}\right.$ percentile $)$ & -0.053 & $-2.49 * *$ & : & -0.211 & -1.36 \\
\hline $\log \left(90^{\text {th }}-50^{\text {th }}\right.$ percentile $)$ & -0.037 & $-2.75 * * *$ & : & -0.152 & -1.60 \\
\hline $\log \left(50^{\text {th }}-10^{\text {th }}\right.$ percentile $)$ & -0.001 & -0.03 & & 0.072 & 0.55 \\
\hline
\end{tabular}

Source: Workplace Employee Relations Survey, 1998. Notes: Each entry in columns (1) and (3) contain the marginal effect. Full sets of explanatory variables have been used in the probit (incidence) and interval data (duration) regressions in columns (1) and (3), in accordance with the results presented in columns (5) and (6) of Tables 2 and 3 . All regressions are fully weighted to allow for stratification and clustering in the sampling procedure. *Statistically significant at $90 \%, * *$ at $95 \%$, and $* * *$ at $99 \%$. 